\title{
One of a Kind, or All of One Kind? Groups of Political Participants and Their Distinctive Outlook on Society
}

\author{
Eefje Steenvoorden ${ }^{1}$ (ID
}

Published online: 29 May 2018

(C) The Author(s) 2018

\begin{abstract}
Political participation can take shape in many types of participation, between which the overlap is low. However, the similarities and differences between various types of participants are surprisingly understudied. In this article, I propose to differentiate between four types of participants: institutional political participants, non-institutional political participants, civic participants, and political consumers. These types differ from each other on two dimensions: whether they are political or publicly oriented and whether they are formally or informally organized. Building on the matching hypothesis, I argue that we should differentiate those four types of participants by their outlook on society (societal pessimism, political trust, and social trust). Using data from the European Social Survey 2006, including participants from 19 countries, logistic regressions show that institutional political participants trust politics rather than people, non-institutional political participants are societal pessimists who trust other people, civic participants are societal optimists who trust other people, and political consumers are pessimists who do not trust politics.
\end{abstract}

Keywords Political participation - Civic participation . Societal pessimism $\cdot$ Political trust $\cdot$ Social trust

Eefje Steenvoorden

E.H.Steenvoorden@uva.nl

1 Department of Political Science, University of Amsterdam, Amsterdam, The Netherlands

\section{Introduction}

Political participation can take shape in many ways, from being a member of a political party, or demonstrating against policy proposals, organizing an activist-group event or boycotting products. A consistent, but nonetheless striking finding, is that the overlap between types of participation is weak to moderate (Dekker et al. 1997; Teorell et al. 2007; Van der Meer 2009; Verba and Nie 1972). This low overlap points to the relevance of understanding differences among types of participants. It raises the question to what extent participants in different forms of political participation are all of one kind, or instead different types of people.

The question whether participants are the same types of people is very relevant for several reasons. First, understanding the differences among groups of participants is important with respect to the democratic function of participation. If different groups of citizens engage in different types of participation, the voices of those groups are only heard equally loud if all types of participation resonate to the same degree in the political arena, which is not the case (Hooghe and Marien 2012). Second, the proposition that participation levels are declining (Putnam 2000) is often countered by pointing to new, non-institutional forms of participation (Dalton 2008). If some forms of participation are declining while others are rising, it is essential to know what distinguishes participants in these types of participation from each other.

However, this question is understudied in the comprehensive literature on participation, which has mainly focused on its causes. Many studies have examined the factors at play in the case of specific types of participation, such as political consumerism (Stolle et al. 2005), online participation (Oser et al. 2013), various types of civic 
participation (Badescu and Neller 2007; Van der Meer et al. 2009), or causes of a broadly defined type such as civic engagement (Pattie et al. 2003). Studies that do compare various types of participants aim to test general patterns, rather than differences between participants (Badescu and Neller 2007; Johann 2012), or focus on the variety of activities people engage in instead of differentiating between activities (Amnå and Ekman 2014; Oser 2016)

This leaves the differences and similarities between participants engaged in different fields of society understudied. This article aims to differentiate between four types of political participation, building on the typology proposed by Van Deth (2014), and proposes two dimensions on which these four types of participation differ: political vs public orientation and formal vs informal organizational structure. It examines to what extent institutional political participants, non-institutional political participants, civic participants, and political consumers are the same kind of people.

I propose to differentiate these types of participants by moving beyond established factors in participation research such as resources, interests, and efficacy. Although these factors clearly explain why people participate, they are likely to be high among all participants and unlikely to differentiate between types of participants. Building on insights from studies that propose the "matching hypothesis" (Clary et al. 1998; Clary and Snyder 1999; Granik 2005), I assume that people participate in an organization, movement or initiative that matches their societal outlook. I expect three aspects of the societal outlook to differentiate among participants: societal pessimism, political trust and social trust.

In what follows, I first discuss the typology of participation used in this article, the formal/informal and political/public dimensions in which the four types of participation differ, and why societal outlook can be expected to differentiate participants from each other. After discussing the choice of data and method, I present the logistic regressions' results and finally I turn to the conclusions and implications.

\section{Theory}

\section{Types of Participation}

The comprehensive literature on civic engagement lacks consensus on both a definition of civic engagement or the less broad concept of political participation, and the types of participation that these definitions encompass (Adler and Goggin 2005; Berger 2009; Van Deth 2014). Consequently, the typologies of participation used are also diverse. Some studies consider civic engagement and examine all types of civic and political participation in the public domain (Brady et al. 1995; Pattie et al. 2003). Many focus on either political (Cohen et al. 2001; Scott and Acock 1979; Teorell et al. 2007; Vecchione and Caprara 2009) or civic participation (Badescu and Neller 2007; Van der Meer et al. 2009). Some focus on non-institutional political participation such as consumer participation (Stolle et al. 2005), or the difference between online and offline participation (Oser et al. 2013). Some authors compare between institutional and non-institutional political participation (Ekman and Amnå 2012; Hooghe and Marien 2013; Sabucedo and Arce 1991), between individual and collective participation (Ekman and Amnå 2012; Pattie et al. 2003; Quintelier and Hooghe 2012; Van Deth 2012), or between types of disengagement and activity (Amnå and Ekman 2014; Oser 2016).

A consistent, striking finding is that the overlap between types of participation is weak to moderate (Verba and Nie 1972; Dekker et al. 1997; Teorell et al. 2007; Van der Meer 2009). A mean correlation of .25 across thirteen types of participation indicates a "weak unitary model of participation," whereas within categories, the correlations are moderate but not high, except for different instances of voting (Verba and Nie 1972: 58-59). These outcomes point to the relevance of both categorizing types of participation and understanding differences among types of participants.

The typology used here builds on the conceptualization and categorization of political participation of Van Deth (2014). After narrowing political participation to voluntary activities by citizens, he distinguishes four types of political participation: (1) activities in the sphere of politics/government/the state, (2) activities targeted at the sphere of politics/government/the state, (3) activities aimed at solving collective or community problems, and (4) activities used to express political aims and intentions. I use these four types under the following common labels: (1) institutional political participation, (2) non-institutional political participation, (3) civic participation and (4) political consumerism. This typology of Van Deth (2014) stands out in two ways. First, in contrast to other studies (e.g., Hooghe and Marien 2013; Marien et al. 2010), he distinguishes political consumerism from non-institutional political participation, such as demonstrating and signing petitions. The rationale for this distinction is that boycotting products itself is not a political activity, but the intentions behind it (can) make it political. Still, the focus of this type of participation is not necessarily the political realm, but can also be for instance producers and multinationals. Second, he calls all these four types of participation political participation, in contrast to authors that define participation belonging in the third category as civic and/or social 
Table 1 Two dimensions in types of political participation

\begin{tabular}{llll}
\hline & Main focus of actions & Public \\
\cline { 3 - 4 } & & Political & \multirow{2}{*}{ Civic participation } \\
\hline Organizational structure & Formal & Institutional political participation & Political consumerism \\
& Informal & Non-institutional political participation & . \\
\hline
\end{tabular}

participation (Badescu and Neller 2007; Van der Meer et al. 2009).

I use the typology of Van Deth (2014) with one adaptation, namely the meaning of civic participation. He defines this in a very broad way, including neighborhoods committees and street parties. Instead, I narrow civic participation here to activities that aim to improve society, such as participation in interest groups and charity organizations. Events with a purely social character, such street barbeques and leisure groups, I do not include, because I assume that the motivation to join these groups and or events is not (partly) related to aims of societal change.

Institutional political participation can be defined as "all acts directly related to the institutional process" (Hooghe and Marien 2013: 133). ${ }^{1}$ Acts of non-institutional political participation can be characterized as attempts to influence the state or politics from outside the political system (Hooghe and Marien 2013; Sabucedo and Arce 1991). Building on the literature (Badescu and Neller 2007; Van der Meer 2009; Van Deth 2014), civic participation in this article refers to voluntary participation in organizations in the public domain but outside the institutional political domain, which aim to contribute to a specific collective problem or a specific community. It includes interest groups and activists groups, charitable organizations and citizens' initiatives (Badescu and Neller 2007; Van der Meer et al. 2009). Finally, political consumerism can be defined as "consumer choice of producers and products based on political or ethical considerations, or both" (Stolle et al. 2005: 246).

These four types of participation all aim to improve society, but in different ways. Table 1 presents a two by two table that presents two dimensions on which these four types of participation differ: the extent to which the aims are political or public and the extent to which the participation is embedded in a formal organizational structure or an informal one. First, institutional political participation and non-institutional political participation both aim to influence political actors, such as politicians, Parliament

\footnotetext{
${ }^{1}$ Electoral participation is not included for several reasons: (1) differences between electoral systems result in different types of vote options (2) A protest vote as an alternative to abstention is determined by the presence of anti-system parties (3) voting is an atypical form of participation, because it is it is explicitly requested by the state, and it requires little time and effort.
}

and/or the government, while civic participation and political consumerism as conceptualized above focus more broadly at society at large, including, but not firstly or mostly, the political domain. Second, the four types of participation differ in organizational structure. It goes without saying that institutional political participation takes place in a formal, organized group, namely political parties and/or institutions. Also civic participation usually takes place in an organizational setting. In comparison, both noninstitutional political participation and political consumerism are rather informal, as they take place outside institutions and organizations and rely on ad hoc participation. Although, of course, actions can be initiated by more long-term action groups, people in protest types of participation such as demonstrations or signing petitions can, but do not need to, commit to more than occasional engagement. Political consumerism is even an individual act that occurs outside any organizational setting, although people can be and/or feel part of a larger movement. In contrast, institutional political participation and civic participation take place in (more) formal organizations and demand more long-term commitment from the start.

\section{Differentiating Participants by Their Outlook on Society}

Surprisingly, the literature does not offer a clear expectation which characteristics can differentiate between participants. The central focus of the literature has been not on which type of participation people engage in, but on explaining why people participate, yielding established factors of participation, such as resources (as in time, money, education, or income), political efficacy, political interest, social network, and incentives or motivations (e.g., Clary et al. 1998; Granik 2005; Pattie et al. 2004).

However, individuals in different types of participation are likely to score similarly on these established factors. From the studies that compare various groups of participants, it can be concluded that although the effect sizes of these factors may differ to some extent, the direction of the effects is the same (Badescu and Neller 2007; Hooghe and Marien 2013; Johann 2012; Marien et al. 2010; Quintelier and Hooghe 2012; Van der Meer et al. 2009; Van Deth 2012). For instance, people involved in boycotting are not distinct from the other types of participants under study 
(Van Deth 2012). Two studies on types of civic participants also show no diverging patterns in the characteristics studied (namely, education, employment, size of locality, network, social trust, church attendance and civic duty), only a smaller or larger influence of the characteristics considered (Badescu and Neller 2007), or only a difference in source of income but not in educational level, income level or political interest (Van der Meer et al. 2009). It is likely that the similarity of the effects of the established factors lies in similar mechanisms driving them (Bekkers and Wiepking 2011). Two exceptions are demographic characteristics, namely age and gender. Younger people ( $<45$ years) and women tend to be more often active in non-institutionalized political participation, while men and older citizens instead are more often involved in institutionalized political participation (Hooghe and Marien 2013; Stolle and Hooghe 2011).

In contrast to the established factors, on which groups of participants often score similarly, several studies indicate that social attitudes do differentiate between types of participants (e.g., Hooghe and Marien 2013; Stolle and Hooghe 2011). Building on those insights, this article suggests to focus on the societal outlook in order to distinguish groups of participants. It is likely that people participate in an organization, group or movement of people who "think like them," i.e., who have the same worldview. Clary and Snyder propose the "matching hypothesis," which states that participation results from congruence between individual and organizational values (Clary et al. 1998; Clary and Snyder 1999; Granik 2005). They show that indeed values, namely: "I feel compassion toward people in need," "I feel it is important to help others," "I can do something for a cause that is important to me" matter in distinguishing non-participants from participants, but they conclude the article by stating that it is likely that different types of participation differ in specific motivations, and that this asks for further study (Clary et al. 1998). Building on this, I theorize that values, such as how important it is to people to contribute to society and/or other people might explain who participates, and that more specific views, namely attitudes, explain which type of participation people engage in.

Before discussing the attitudes that I expect to differentiate between participants and why, I want to stress that the causality of the association between attitudes and participation is not addressed here. My aim is to differentiate types of participants from each other, and not to examine whether the differentiation took place before or because of people's participation.

\section{Patterns of Societal Pessimism, Political Trust, and Social Trust Among Participants}

How do the three attitudes differentiate among the four types of participants? Many studies on participation include political or social trust, or they focus on a specific type of participation, rather than comparing multiple groups (Allum et al. 2010; Hooghe and Marien 2013; Kaase 1999; Stolle et al. 2005; Suh et al. 2013). Below, I theorize why societal pessimism, political trust, and social trust are likely to differentiate the four types of participants from each other.

The few studies on societal pessimism show that a large part of the citizenry in advanced western democracies can be described as pessimistic about society (European Commission 2013; Gallup 2014; Steenvoorden and Van der Meer 2017). Societal pessimism can be defined as a sentiment among citizens that their society is in decline and refers to a sense of unmanageable deterioration of society and collective powerlessness ${ }^{2}$ to stop that deterioration (Steenvoorden 2015). Other related concepts are cultural pessimism (Bennett 2001), social actualization, the "evaluation of the potential and trajectory of society" (Keyes 1998: 122), and optimism, "a view that the future will be better than the past and the belief that we can control our environment so as to make it better" (Uslaner 2002: 81). To my knowledge, the only previous study on societal pessimism and participation is that of Uslaner and Brown (2005), who find a negative relationship between societal optimism and political institutional, political non-institutional and civic participation, but their aggregated, statelevel data from the USA do not inform us on the individual-level relations in which I am interested here.

If people perceive unmanageable societal deterioration, and collective powerlessness to stop the decline, it is unlikely that they expect improvement in our conditions can easily be made. I expect societal pessimism to indicate whether people believe change is possible within institutions or organizations (political and non-political), or whether they instead do not expect that change can be (easily) established and are primarily interested in expressing their discontent through protest. This means that I think that societal pessimism distinguishes between institutional political participation and civic participation, on the one hand, and non-institutional political participation and political consumerism, on the other hand.

Given the overlap in types of participation it is theoretically-and, as I will show, empirically-unjust to

\footnotetext{
2 In contrast to common usage of powerlessness, referring to individuals who feel powerless to do something, collective powerlessness does not refer to one's own possibilities to make changes, but distrust in society's capacity to make changes.
} 
formulate hypotheses on mutually exclusive groups. Moreover, differentiating between all possible combinations of participation would give us no theoretical grounds to build the expectations on. Therefore, I use hypotheses that describe the relationships between attitudes and types of participation, not comparisons of types of participation.

H1: societal pessimism is negatively related to institutional political participation

H2: societal pessimism is positively related to noninstitutional political participation

H3: societal pessimism is negatively related to civic participation

H4: societal pessimism is positively related to political consumerism

Both political trust and social trust can be expected to offer insight into whether people want to participate within or outside the political institutional domain. Starting with political trust, we have to differentiate between trust in the political community, the political regime (performance and institutions), and the political authorities or incumbents (Easton 1975; Norris 2011). Here, I focus on trust in the political regime and political authorities: It is likely that people engage in participation because they are either dissatisfied or inspired by the political leaders and political institutions in their country, and not so much the political community. One applicable definition of political trust is that it is "the probability ... that the political system (or some part of it) will produce preferred outcomes even if left unattended" (Gamson 1968: 54).

Research that compares participants to the general population demonstrates that participants' levels of political trust vary. Political trust is found to be positively related to institutional political participation but negatively related to non-institutional political participation (Barnes and Kaase 1979; Hooghe and Marien 2013; Vráblíková 2013) and political consumerism (Newman and Bartels 2011; Stolle et al. 2005). Intuitively, this makes sense: Why would one engage in a political party if one does not trust political parties, politicians, or the political system? Conversely, if you distrust political institutions and authorities, it is likely that you express your dissatisfaction or frustration with how things are going or decisions made outside the political setting, thus in non-institutional political participation and/or political consumerism. Therefore, I follow this logic in comparing participants only.

To my knowledge, the relationship between political trust and civic participation is only sporadically discussed in the literature. The few available studies show that people involved in civic participation are politically distrustful (Brehm and Rahn 1997; Eliasoph 1998). Brehm and Rahn theorize that this negative relationship follows from a do-it- yourself mentality (1997). Therefore, I expect civic participants to be political distrustful compared to other participants. With regard to political trust, I formulate the following hypotheses:

H5: political trust is positively related to institutional political participation

H6: political trust is negatively related to non-institutional political participation

H7: political trust is negatively related to civic participation

H8: political trust is negatively related to political consumerism

Two streams of literature suggest different conceptualizations of social trust, namely strategic trust (based on one's interests), which follows a rational choice logic (Hardin 2002), and generalized trust (based on an outlook on human nature), which sees trust as resulting from culture and socialization (Uslaner 2002). Following the literature on participation, I focus on generalized social trust. This can be defined as "the idea that most people can be trusted" (Uslaner 2002: 5) and is based on "the perception that most people are part of your moral community" (Uslaner 2002: 26).

Although cause and consequence are debated, social trust, as a form of social capital, is seen as one of the merits of social and civic involvement (Putnam 1993, 2000). It stimulates and results from participation in organizations, actions, or initiatives of that community and thereby overcomes collective action problems in producing public goods (for an overview of the literature, see Van Deth 2001). Many studies that compare participants to the general population show that social trust is positively related to civic participation (e.g., Badescu and Neller 2007; Dekker et al. 1997; Uslaner and Brown 2005).

In the case of non-institutional political participation and political consumerism, social trust can overcome collective action problems. Social trust can be expected to have a positive effect because "the threshold for political action for trusting individuals should be lower than for non-trusting individuals because the former have more generous estimates of the number of people who will join them in protest" (Benson and Rochon 2004: 438). This increases the perceived likeliness that a protest will have results; if many people join, it is more likely to have consequences. The positive relationship between social trust and non-institutional political participation is indeed underlined by many studies (Benson and Rochon 2004; Hooghe and Marien 2013; Kaase 1999). In the case of political consumerism, previous studies find no relationship with social trust (Pattie et al. 2003; Stolle et al. 2005). This could be due to the fact that it is a more individualistic type of participation than non-institutional political 
Table 2 Summary of hypotheses

\begin{tabular}{lllll}
\hline & Institutional political participation & Non-institutional political participation & Civic participation & Political consumerism \\
\hline Societal pessimism & - & + & - & + \\
Political trust & + & - & - & - \\
Social trust & - & + & + & + \\
\hline
\end{tabular}

participation. Nevertheless, it can be expected that people boy/buycott certain products with the idea that they are not the only ones, and that they expect more people to do so.

In contrast, institutional political participation is not per se driven by membership in a generalized community; instead, it is driven by political camps that have very different ideas and values about what should be done. "The spirit of cooperation that underlies generalized trust is absent in political activity, which reinforces particularized trust [trust in your own group] at the expense of generalized trust" (Uslaner and Brown 2005: 875). Therefore, several authors expect and find a negative association between social (generalized) trust and institutional political participation compared to the general population (Hooghe and Marien 2013; Kim 2005; Pattie et al. 2003; Uslaner and Brown 2005). In this article, I follow the result of these studies on the whole population in formulating hypothesis about participants only. Table 2 provides an overview of all of the hypotheses posited in this article.

H9: social trust is negatively related to institutional political participation

H10: social trust is positively related to non-institutional political participation

H11: social trust is positively related to civic participation

H12: social trust is positively related to political consumerism

\section{Data and Method}

\section{Data}

To test the hypotheses, I use the European Social Survey from 2006 (wave 3), which includes variables on not only all four types of participation and the three attitudes under study, but also on many of the established factors of political participation. I included data on individuals 18 years and older from 19 European countries ${ }^{3}$ in the analyses. I excluded Russia and Ukraine because they score

\footnotetext{
3 Austria, Belgium, Bulgaria, Switzerland, Cyprus, Germany, Denmark, Spain, Finland, France, United Kingdom, Ireland, Netherlands, Norway, Poland, Portugal, Sweden, Slovenia, and Slovakia.
}

not/partially free on the Freedom House index ${ }^{4}$ which may affect political participation, and Estonia and Hungary because in these countries level of income is not measured.

The four types of participation are measured by one or several items on specific forms of participation: A yes on one of the items establishes a yes on being such a type of participant. A general introduction preceded eight out of the nine items: "There are different ways of trying to improve things in [country] or help prevent things from going wrong. During the last 12 months, have you done any of the following:" The exception is one item on civic participation, "Involved in work for voluntary or charitable organization". The operationalizations are presented in Table 3, as well as the percentage of respondents involved (including non-participants). All of the items are dummies (did/did not participate in the last 12 months), except for the last item on civic participation, which is recoded to 0 (never) or 1 (ranging from at least every 6 months to at least every week). Respondents with missing values on any of the nine items are excluded from the regression analyses, because they cannot be placed into a group of participants. Among the participants, this applies to 293 respondents, resulting in a final number of 15,321 respondents. Table 3 shows that civic participation (43\%) is relatively popular compared to institutional political participation (23\%), non-institutional political participation (27\%), and political consumerism (17\%). It also tells us that $38 \%$ of respondents do not participate in any form of participation measured here.

Table 4 shows the percentages of all possible participation combinations, from which follows that half (49\%) of all participants engage in only one type of political participation, $28 \%$ of respondents is involved in two types of participation, $16 \%$ in three types, and $6 \%$ in all four types. We can conclude on the one hand that the largest group of participants engages in one type of participation, as suggested in the literature (Keeter et al. 2002; Verba and Nie 1972). On the other hand, the overlap indicates that we cannot view these types of participants as entirely different people. Therefore, I control for this overlap in the analyses, which I clarify in the next section.

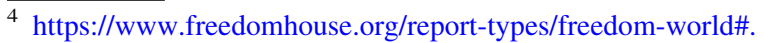
VJBZ83trVkh.
} 
Table 3 Measures of types of political participation (in \%). Source: European Social Survey 2006

\begin{tabular}{|c|c|c|}
\hline & No & Yes \\
\hline Institutional political participation & 77 & 23 \\
\hline Member of political party & 95 & 6 \\
\hline Contacted politician or government official & 85 & 15 \\
\hline Worked in political party or action group & 96 & 4 \\
\hline Worn or displayed campaign badge/sticker & 92 & 8 \\
\hline Non-institutional political participation & 68 & 27 \\
\hline Signed petition & 76 & 25 \\
\hline Taken part in lawful public demonstration & 94 & 6 \\
\hline Civic participation & 42 & 43 \\
\hline Worked in another organization or association & 85 & 16 \\
\hline Involved in work for voluntary or charitable organizations & 62 & 40 \\
\hline Political consumerism & 83 & 17 \\
\hline Boycotted certain products & 83 & 17 \\
\hline No participation & 62 & 38 \\
\hline
\end{tabular}

All items but one ("Involved in work for voluntary or charitable organizations") answer the following question: "There are different ways of trying to improve things in [country] or help prevent things from going wrong. During the last 12 months, have you done any of the following"

Table 4 Overlap between types of political participation

\begin{tabular}{lr}
\hline Type of participation & $\%$ \\
\hline One type & 49 \\
Institutional political participation & 7 \\
Non-institutional political participation & 9 \\
Civic participation & 29 \\
Political consumerism & 4 \\
Two types & 28 \\
Political participation & 3 \\
Formal participation & 9 \\
Public participation & 4 \\
Informal participation & 3 \\
Institutional political participation and political consumerism & 1 \\
Non-institutional political participation and civic participation & 8 \\
Three types & 16 \\
Institutional political participation and non-institutional political participation and civic participation & 8 \\
Non-institutional political participation and civic participation and political consumerism & 4 \\
Institutional political participation and civic participation and political consumerism & 2 \\
Institutional political participation and non-institutional political participation and political consumerism & 2 \\
Four types & 6 \\
\hline
\end{tabular}

Turning to the independent variables, societal pessimism is measured by the sum score of two items: "For most people in [country], life is getting worse" and "Hard to be hopeful about the future of the world" $(r=.48) .^{5}$ These items both adequately measure the core of societal

\footnotetext{
5 The reported correlations are polychoric correlations in this article in the case of the 1-5 Likert scales.
}

pessimism, given that they capture a diffuse concern about society in general going in the wrong direction. Although ideally this correlation would be higher, it is not overly surprising, given the fact the first item is more socioeconomic and the second is very general. Because both aspects are important to include in a measure of societal pessimism, the best option use them both. Moreover, these two 
items are also used in previous studies on societal pessimism (Steenvoorden and Harteveld 2017) and on related concepts like social actualization "the world is becoming a better place for everyone" (Keyes 1998; Keyes and Shapiro 2004) and (a lack of) optimism, "the lot of the average person is getting worse" (Uslaner 2002; Uslaner and Brown 2005).

Political trust is measured by the sum score of three items, which ask people how much they trust politicians, political parties, and Parliament on a scale from 0 to 10 . These items show correlations ranging from .69 to .86 . Social trust is also measured by the sum score of three items on a scale from 0 to 10: "Most of the time people are helpful or mostly looking out for themselves," "Most people try to take advantage of you if they had the chance, or try to be fair," and "Most people can be trusted or you can't be too careful in dealing with people". The correlations range from .49 to .57 . I standardized the resulting scales of societal pessimism, political trust, and social trust to facilitate direct coefficient comparison within models. The scales correlate at -.35 (societal pessimism and political trust), -.35 (societal pessimism and social trust), and .42 (political trust and social trust). ${ }^{6}$

Of course, I control for a range of factors that are known in the literature to affect participation (e.g., Armingeon 2007; Badescu and Neller 2007). For example, gender, age groups $(18-34,35-54,55+)$, resident in a rural area or small city versus (the suburbs of) a large city, marital status (married or official partner vs. divorced/separated, widowed or single), size of household, number of children, and level of religiosity ("How often attend religious services apart from special occasions," ranging 1-7: never to every day) are included as established demographic factors related to political participation. As an assurance that the measure of societal pessimism reflects only sociotropic concerns, I include a variable on satisfaction with life as a whole, ranging from 0 to $10 .^{7}$

I also control for established factors in participation research, namely resources, political interest, and political efficacy. Resources are operationalized with educational level (low, medium, or high), source of income (salary or profit vs. pension, unemployment benefit, other benefit or other source), and level of income (household's total net income, in 12 categories). Political interest is measured with two variables: An item asking how interested one is in politics on a 1-4 scale, and the ratio of time spent following political news and current affairs on TV to all time spent watching TV. Political efficacy is measured by the sum score of two items: "Politics is too complicated to

\footnotetext{
${ }^{6}$ As a robustness check, I created factor scores instead of scales based on sum scores. The results lead to the same conclusions.

${ }^{7}$ Excluding this variable yields the same conclusions.
}

understand" (reversed) and "Making mind up about political issues," ranging from 1 to 5 , indicating very difficult to very easy $(r=.49)$.

\section{Method}

Because the four groups of participants overlap, separate logistic regression analyses for the four types of participation are the most appropriate research method. This is to be preferred over excluding participants in more than one type of participation, which non-randomly excludes $51 \%$ of all respondents, or to perform multinomial analysis on all groups in Table 3, which would disable a comparison of four types of participation. Still, controlling for the overlap in types of participation is needed because the people who participate in more than one type come from a specific group - the relatively highly educated and efficaciouswhich otherwise dominates the analyses and yields different results. Therefore, I include a dummy in all analyses, which is 1 when respondents participate in more than one type of participation. This means the higher chance of participation for people engaged in two, three, or four types is accounted for with the dummy and does not mediate through other variables. ${ }^{8}$ As mentioned above, all nonparticipants are excluded from the analyses, because they are not the focus of this study and might blur the differences between types of participation. The results of the logistic regressions of the four types of participation are then compared to draw conclusions. In all regressions, I eliminate all cross-national variance in the dependent variables by including country dummies and deal with the error structure by using clustered robust standard errors. As robustness checks, I repeated the logistic analyses for the nine items that constitute the four types of participation separately and I repeated the analyses with non-participants (see Appendix Table 10).

\section{Results}

\section{Correlations Between Types of Participation}

To examine the interrelatedness of the forms of participation, I show the correlations between all nine items on political participation (within-type correlations in boxes). In the literature, correlations are often reported to be low $(.0-.3)$ to moderate $(.3-.5)$ between types of participation, whereas within types of participation correlations range

\footnotetext{
$\overline{8}$ As a result, the reference category in each analysis indicates people who do not participate in that way, and also not in more than one way of the four ways.
} 
Table 5 Correlations between the items on participation including non-participants. Source: European Social Survey 2006

\begin{tabular}{|c|c|c|c|c|c|c|c|c|}
\hline & 1 & 2 & 3 & 4 & 5 & 6 & 7 & 8 \\
\hline 1. member of a political party & 1 & & & & & & & \\
\hline 2. contacted a politician & .45 & 1 & & & & & & \\
\hline 3. worked in political organization & .79 & .62 & 1 & & & & & \\
\hline 4. worn or displayed badge & .39 & .39 & .56 & 1 & & & & \\
\hline 5. signed a petition & .16 & .37 & .37 & .52 & 1 & & & \\
\hline 6. demonstrated & .21 & .32 & .48 & .57 & .57 & 1 & & \\
\hline 7. worked in civic organization & .39 & .49 & .58 & .51 & .43 & .37 & 1 & \\
\hline 8. voluntary organization & .27 & .35 & .38 & .35 & .30 & .25 & .60 & 1 \\
\hline 9. boycotted products & .08 & .31 & .23 & .39 & .52 & .39 & .35 & .26 \\
\hline
\end{tabular}

These are tetrachoric correlations because the variables are dummies. The correlations shown are significant at $p<.05$

Table 6 Correlations between the items on participation excluding non-participants. Source: European Social Survey 2006

\begin{tabular}{|c|c|c|c|c|c|c|c|c|}
\hline & 1 & 2 & 3 & 4 & 5 & 6 & 7 & 8 \\
\hline 1. member of a political party & 1 & & & & & & & \\
\hline 2. contacted a politician & .31 & 1 & & & & & & \\
\hline 3. worked in political organization & .74 & .52 & 1 & & & & & \\
\hline 4. worn or displayed badge & .27 & .23 & .47 & 1 & & & & \\
\hline 5. signed a petition & -.06 & .11 & .19 & .33 & 1 & & & \\
\hline 6. demonstrated & .08 & .16 & .38 & .47 & .41 & 1 & & \\
\hline 7. worked in civic organization & .23 & .31 & .46 & .36 & .17 & .21 & 1 & \\
\hline 8. voluntary organization & -.04 & -.05 & .11 & & -.27 & -.08 & .30 & 1 \\
\hline 9. boycotted products & -.11 & .08 & .06 & .22 & .29 & .23 & .13 & -.19 \\
\hline
\end{tabular}

These are tetrachoric correlations because the variables are dummies. The correlations shown are significant at $p<.05$

widely, from low to strong (> .5) (Teorell et al. 2007; Verba and Nie 1972). Table 5 indeed shows that correlations between types of participation are mostly low to moderate, with a few exceptions (such as wearing a badge), and that within-type correlations vary considerably, from .39 to .79 .

Table 6, shows the correlations for the participants only, as the logistic regressions also exclude non-participants. And that paints a different picture: correlations are overall much lower, some lose significance (and therefore not reported), and some turn out to be negative. From the differences between Tables 5 and 6, we can draw several important conclusions. First, correlations between types of participation are "artificially" high because non-participation on one type is positively related to non-participation on another type. Second, participation in one type does not always increase participation in another type. Instead, some types of participation show a negative correlation, meaning the opposite is in fact true. Finally, these correlations underline the need to establish what differentiates types of participants, because they are even less alike when we look at them without the "noise" of the non-participants.

\section{Examining Differences Among Types of Participants}

Table 7 shows the results of the logistic regression analyses (the country dummies are not shown for reasons of space), and Table 8 summarizes which hypotheses are supported and which are rejected (the latter between brackets). If we first look at the coefficients of societal pessimism, the results are in line with three of the four hypotheses on this attitude. Societal pessimism is positively related to noninstitutional political participation and political consumerism, which means that people involved in both noninstitutionalized, protest types of participation (namely demonstrating and signing petitions) as well as political consumerism (boycotting products) are indeed relatively pessimistic about society, which is in line with $\mathrm{H} 2$ and $\mathrm{H} 4$. The significant negative relationship between societal pessimism and civic participation supports $\mathrm{H} 3$; civic participants are relatively optimistic about society. However, the relationship between societal pessimism and institutional political participation is not significant and the expected negative relationship (H1) is not supported by the data. 
Table 7 Logistic regression analyses of four types of political participation. Source: European Social Survey 2006

\begin{tabular}{|c|c|c|c|c|c|c|c|c|}
\hline & \multicolumn{2}{|c|}{$\begin{array}{l}\text { Institutional political } \\
\text { participation }\end{array}$} & \multicolumn{2}{|c|}{$\begin{array}{l}\text { Non-institutional political } \\
\text { participation }\end{array}$} & \multicolumn{2}{|c|}{ Civic participation } & \multicolumn{2}{|c|}{$\begin{array}{l}\text { Political } \\
\text { consumerism }\end{array}$} \\
\hline & $b$ & se & $b$ & se & $b$ & se & $b$ & se \\
\hline \multicolumn{9}{|l|}{ Demographic characteristics } \\
\hline Male & $0.13 * *$ & $(0.06)$ & $-0.29 * * *$ & $(0.06)$ & $0.28 * * *$ & $(0.08)$ & $-0.36^{* * *}$ & $(0.08)$ \\
\hline \multicolumn{9}{|l|}{ Age (18-34) } \\
\hline $35-54$ & $0.14 * *$ & $(0.07)$ & $-0.28 * *$ & $(0.10)$ & 0.12 & $(0.08)$ & 0.12 & $(0.09)$ \\
\hline $55+$ & $0.33 * * *$ & $(0.07)$ & $-0.48 * * *$ & $(0.13)$ & 0.08 & $(0.12)$ & 0.11 & $(0.08)$ \\
\hline City & $-0.25^{* * *}$ & $(0.05)$ & $0.27 * * *$ & $(0.06)$ & $-0.24 * * *$ & $(0.07)$ & $0.27 * * *$ & $(0.05)$ \\
\hline \multicolumn{9}{|l|}{ Marital status (married or partnership) } \\
\hline Divorced or separated & 0.06 & $(0.07)$ & $0.18 * *$ & $(0.07)$ & $-0.12 *$ & $(0.07)$ & 0.09 & $(0.09)$ \\
\hline Widowed or partner died & -0.12 & $(0.09)$ & 0.08 & $(0.12)$ & 0.01 & $(0.10)$ & $-0.17 *$ & $(0.09)$ \\
\hline Single & -0.10 & $(0.07)$ & $0.21 * *$ & $(0.07)$ & -0.09 & $(0.05)$ & $0.12 * *$ & $(0.04)$ \\
\hline Household size & $0.04 * *$ & $(0.02)$ & 0.00 & $(0.03)$ & $0.08 * * *$ & $(0.02)$ & $-0.07 * *$ & $(0.02)$ \\
\hline Children living at home & $-0.11 *$ & $(0.06)$ & 0.07 & $(0.07)$ & $-0.14 * *$ & $(0.07)$ & $0.14 * *$ & $(0.06)$ \\
\hline Attendance religious services & 0.01 & $(0.02)$ & $-0.11 * * *$ & $(0.02)$ & $0.26 * * *$ & $(0.02)$ & $-0.14 * * *$ & $(0.02)$ \\
\hline Satisfaction with life & -0.01 & $(0.01)$ & $-0.02^{*}$ & $(0.01)$ & $0.03 * *$ & $(0.01)$ & -0.02 & $(0.01)$ \\
\hline \multicolumn{9}{|l|}{ Resources } \\
\hline \multicolumn{9}{|l|}{ Education (medium) } \\
\hline Low & 0.14 & $(0.09)$ & -0.11 & $(0.07)$ & -0.09 & $(0.07)$ & $-0.29 * * *$ & $(0.06)$ \\
\hline High & 0.09 & $(0.06)$ & 0.05 & $(0.07)$ & $0.10^{*}$ & $(0.06)$ & 0.07 & $(0.06)$ \\
\hline \multicolumn{9}{|l|}{ Source of income (profit/salary) } \\
\hline Pension & 0.05 & $(0.07)$ & $-0.15^{* *}$ & $(0.07)$ & 0.08 & $(0.05)$ & $-0.12 *$ & $(0.07)$ \\
\hline Unemployment benefit & $0.52 * *$ & $(0.16)$ & -0.05 & $(0.08)$ & -0.05 & $(0.12)$ & 0.05 & $(0.15)$ \\
\hline Other benefit & 0.24 & $(0.21)$ & 0.18 & $(0.21)$ & 0.11 & $(0.19)$ & -0.20 & $(0.13)$ \\
\hline Other & 0.14 & $(0.13)$ & 0.04 & $(0.15)$ & $0.20 * *$ & $(0.09)$ & 0.10 & $(0.15)$ \\
\hline Household income & $-0.04 * *$ & $(0.02)$ & -0.01 & $(0.02)$ & 0.02 & $(0.02)$ & 0.02 & $(0.02)$ \\
\hline \multicolumn{9}{|l|}{ Political interest and efficacy } \\
\hline Ratio political news/all news & 0.03 & $(0.07)$ & $-0.19 * *$ & $(0.07)$ & $0.21 * *$ & $(0.08)$ & $0.37 * * *$ & $(0.09)$ \\
\hline Political interest & $0.29 * * *$ & $(0.03)$ & $0.07 * *$ & $(0.02)$ & $-0.14 * * *$ & $(0.03)$ & $0.21 * * *$ & $(0.05)$ \\
\hline Political efficacy & $0.07 * * *$ & $(0.01)$ & -0.01 & $(0.01)$ & $-0.05^{* *}$ & $(0.02)$ & $0.06 * * *$ & $(0.01)$ \\
\hline \multicolumn{9}{|l|}{ Societal outlook } \\
\hline Societal pessimism & -0.05 & $(0.04)$ & $0.10 * *$ & $(0.03)$ & $-0.14 * * *$ & $(0.03)$ & $0.08 * *$ & $(0.04)$ \\
\hline Political trust & $0.11 * *$ & $(0.04)$ & -0.04 & $(0.03)$ & 0.04 & $(0.03)$ & $-0.22 * * *$ & $(0.03)$ \\
\hline Social trust & $-0.15^{* * *}$ & $(0.02)$ & $0.10^{* *}$ & $(0.04)$ & $0.10 * * *$ & $(0.03)$ & 0.02 & $(0.04)$ \\
\hline More than 1 type of participation & $2.43 * * *$ & $(0.08)$ & $2.22 * * *$ & $(0.08)$ & $1.45 * * *$ & $(0.07)$ & $1.97 * * *$ & $(0.07)$ \\
\hline
\end{tabular}

Coefficients are $\log$ odds, with $* p<0.05 ; * * p<0.01 ; * * * p<0.001$ (one-sided tests)

Table 8 Supported and rejected (between brackets) hypotheses

\begin{tabular}{lllll}
\hline & $\begin{array}{l}\text { Institutional political } \\
\text { participation }\end{array}$ & $\begin{array}{l}\text { Non-institutional political } \\
\text { participation }\end{array}$ & $\begin{array}{l}\text { Civic } \\
\text { participation }\end{array}$ & $\begin{array}{l}\text { Political } \\
\text { consumerism }\end{array}$ \\
\hline Societal pessimism & $(-)$ & + & - & + \\
Political trust & + & $(-)$ & $(-)$ & - \\
Social trust & - & + & + & $(+)$ \\
\hline
\end{tabular}


When we turn to political trust, we see that people involved in political parties and with politicians indeed are more trusting of these actors and institutions than people who do not participate in this way, in line with H5. The expected negative relationship with political consumerism (H8) is also supported. Surprisingly, this is not the case for non-institutional political participation. In contrast to previous studies that measure non-institutional political participation including boycotting (Barnes and Kaase 1979; Hooghe and Marien 2013; Vráblíková 2013), the current measure with only demonstrating and signing petitions does not find this negative relationship with political trust. Possible, the effect found in previous studies is mainly driven by boycotting. Also the hypothesis on the negative relationship between political trust and civic participation needs to be rejected. This differs from in earlier studies that report this group as low in political trust (Brehm and Rahn 1997; Eliasoph 1998). An explanation for this different finding could be that these previous studies focus on a broader range of civic participation and that they include social participation. The unexpected non-findings in the case of $\mathrm{H} 6$ and $\mathrm{H} 7$ could also be the result of the fact that non-participants are excluded here, in contrast to previous studies. That turns out not to be the case: the analyses in Table 10 in the Appendix include non-participants and yield the same conclusions with regard to $\mathrm{H6}$ and $\mathrm{H7}$.

Moving on to social trust, Table 7 shows social trust to be negatively related to institutional political participation, as hypothesized (H9). People involved in institutional politics are less trusting of the general other than are other types of participants, and social trust is positively related to civic participation (H10) and non-institutional political participation (H11), also in line with my expectations. However, social trust does not relate significantly to political consumerism. This is in line with previous studies (Pattie et al. 2003; Stolle et al. 2005) and may underline the individual nature of political consumerism. It also stresses the need to differentiate political consumerism from noninstitutional political participation.

Overall, the results support eight out of the twelve hypotheses on the relationships between the three societal attitudes and four types of participation. The societal outlook of the four groups of participants can be summarized as follows: Institutional political participants trust politics rather than people, non-institutional political participants are societal pessimists who trust other people, civic participants are societal optimists who trust other people, and political consumers are pessimists who do not trust politics.

Several of the control variables also show significance in differentiating between types of participation. Men are more often involved in formal and women in informal participation. The youngest age group (18-35) is more often involved in political non-institutional political participation, whereas the oldest age group $(55+)$ is more often involved in institutional political participation. Urban inhabitants and singles are more often non-institutional political participants and political consumerism, while in rural areas the other two types of participation are more common. Children living at home increase the chance on political consumerism, but decrease civic participation. Low-educated people are less likely to be political consumers, and the unemployed are more likely to engage in institutional political participation. Civic participants are less politically interested or politically efficacious than the other three groups. Political consumers stand out in their attention to political news.

As a robustness check, I analyzed the nine participation items separately with logistic regressions to check whether this yields the same results. Table 9 shows the effects of the individual items per type of participation, with significant effects ( $p<.05$, one-sided tests) indicated by plus and minus signs, and a non-significant effect indicated by an empty cell. It shows that there are three notable exceptions from the general pattern. One is the negative relationship between societal pessimism and contacting a politician, which is in line with hypothesis 1 , but does not show for the institutional political participation category as a whole. A second exception is the negative relationship between political trust and signing petition. However, the positive coefficient for signing petition is only just significant $[-0.05(\mathrm{se}=0.03)]$, in contrast to the coefficient of boycotting, which is very convincingly significant $[-0.22$ ( $\mathrm{se}=0.03)]$. Therefore, the negative sign of political trust in the case of signing petition is not a very convincing one and should not alter the conclusions.

Third, it is important to notice that the positive relationship between social trust and non-institutional participation seems to be based on the item signing a petition, as the other item of non-institutional political participation does not show this relationship. This means we should interpret the support for hypothesis 10 with some caution. Overall, it is safe to conclude that within all four types of participation, the effects of societal pessimism, political trust, and social trust are in line with those in Table 7 for most or all of the items on participation.

Finally, I ran the analyses including non-participants, to see whether that blurs the findings as expected. Table 10 in the Appendix shows the results, which are mostly the same, except for the relationship between political trust and noninstitutional participation, which reaches significance, albeit only just. Therefore, it shows that the results are robust, and that in fact it does not alter the conclusions much in this article whether we compare groups of participations to each other or to the whole population, including non-participants. However, some coefficients do change, besides the one on political trust, also those of 
Table 9 Effects of attitudes on forms of institutional political participation, non-institutional political participation, civic participation and political consumerism. Source: European Social Survey 2006

\begin{tabular}{lccc}
\hline & Societal pessimism & Political trust & Social trust \\
\hline Institutional political participation & & + & - \\
Member party & - & + & - \\
Contacted politician & & + & - \\
Worked in political organization & & + & + \\
Worn/displayed badge & + & a $^{\mathrm{a}}$ & \\
Non-institutional political participation & + & & + \\
Signed petition & + & & + \\
Demonstrated & - & & + \\
Civic participation & - & - & + \\
Worked in civic organization & - & - & \\
Voluntary organization & + & & \\
Political consumerism & + & & \\
Boycotted products & & & \\
\hline
\end{tabular}

a- $0.05(0.03)$

b $-0.22(0.03)$

educational level, political interest, and marital status for instance. Therefore, in future research that compares groups of participants to each other, excluding non-participants is the most reliable line of inquiry.

\section{Conclusions and Discussion}

The large literature on participation has focused predominantly on causes of participation, or the characteristics of specific types of participation. While some authors examined the differences between groups of citizens with a small or large a variety of activities (Amnå and Ekman 2014; Johann 2012; Oser 2016), the similarities and differences between participants in different fields of society are understudied. This article proposes to differentiate participants in political participation along two dimensions: politically vs publicly oriented participation and formally vs informally organized participation. These dimensions differentiate between four types of participation, distinguished Van Deth (2014): institutional political participation, non-institutional political participation, civic participation, and political consumerism. Building on the matching hypothesis (Clary and Snyder 1999; Granik 2005), I proposed to differentiate between those four types by the societal outlook of participants. I argued that that people engage in participation in an organization, group, or movement in which people have the same world view, namely in terms of societal pessimism, political trust, and social trust.

As a first step, I find that excluding non-participants from the analyses is quite important if we examine something as straightforward as correlations. These are already only moderate while including participants, but decrease substantially, and in some cases even lose significance or turn out to be negative instead of positive, when non-participants are excluded. This underlines the need to differentiate among types of participants.

The logistic regression analyses support eight of the twelve hypotheses on the relationships between societal pessimism, political trust, and social trust and the four types of participation. If we compare types of participants to each other, we can characterize the institutional political participants as trusting politics rather than people, noninstitutional political participants as societal pessimists who trust other people, civic participants as societal optimists who trust other people, and political consumers as pessimists who do not trust politics.

The finding that non-institutional political participation and political consumerism should be differentiated is most surprising and has also important consequences. In contrast to previous studies into non-institutional political participation, which often include political consumerism in that category (Barnes and Kaase 1979; Hooghe and Marien 2013; Vráblíková 2013), this article shows these two types of participation differ in various respects, most notably in their relationship to political trust, and should be pulled apart in future research. That is in line with the assumption of Almond and Verba, that citizens require positive orientations toward the political system to participate in it, and that negative attitudes toward the political system lead to alienation (1963). Demonstrating and signing petitions, the two operationalizations of non-institutional political participation used here, are not situated in political 
organizations, but are still directed at them. Compared to those types of participation, political consumerism is clearly more distanced from political actors and institutions. The finding that people in the latter distrust politics, while the former do not, means that political distrusting citizens might be more alienated from politics than we assumed.

The results also call for more attention in future research to the constellation of attitudes. The relationship between attitudes is a much debated topic, with some studies that find an effect of social trust on political trust (Bäck and Christensen; Catterberg and Moreno 2006; Keele 2007), whereas in some cases the effect of political trust on social trust is larger than the other way around (Brehm and Rahn 1997; Mishler and Rose 2005; Zmerli and Newton 2017). This article shows that a variety of constellations attitudes can exist, and can distinguish groups of participants from each other. It is therefore important to pay more attention to the causes of such different outlooks on society.

The results also add insight into the alleged decline in participation (Dalton 2004; Putnam 2000). A decline in participation, especially institutional political participation, seems unlikely to be counterbalanced by other types of participation, because they attract different types of people. In addition to the differences in attitudes, the analyses show age differences as well, with for instance relatively young (18-34) non-institutional political participants and older institutional political participants $(55+)$, in line with previous studies (Stolle and Hooghe 2011). These age differences ask for panel research into participation. Are these generational differences or cohort differences? In the latter case, we have little reason to expect that current divisions between groups of participants will diminish over time.

Moreover, because the results show participants to come from different groups, the influence of one type of participation versus others becomes more important. If political participation is seen as a way to raise one's voice and thereby to play an important role in the functioning of democracy, the influence of one type of voice over the other becomes more important when those voices belong to different people. Indeed, types of political participation are rather different in terms of their perceived effectiveness (Hooghe and Marien 2012). This underlines the importance of differentiating types of participation from each other in research on participation.

Open Access This article is distributed under the terms of the Creative Commons Attribution 4.0 International License (http://crea tivecommons.org/licenses/by/4.0/), which permits unrestricted use, distribution, and reproduction in any medium, provided you give appropriate credit to the original author(s) and the source, provide a link to the Creative Commons license, and indicate if changes were made.

\section{Appendix}

See Table 10.

Table 10 Logistic regression analyses of four types of political participation and non-participants. Source: European Social Survey 2006

\begin{tabular}{|c|c|c|c|c|c|c|c|c|c|c|}
\hline & \multicolumn{2}{|c|}{$\begin{array}{l}\text { Institutional } \\
\text { political } \\
\text { participation }\end{array}$} & \multicolumn{2}{|c|}{$\begin{array}{l}\text { Non-institutional } \\
\text { political } \\
\text { participation }\end{array}$} & \multicolumn{2}{|c|}{ Civic participation } & \multicolumn{2}{|c|}{$\begin{array}{l}\text { Political } \\
\text { consumerism }\end{array}$} & \multicolumn{2}{|c|}{ Non-participants } \\
\hline & $b$ & se & $b$ & se & $b$ & se & $b$ & se & $b$ & se \\
\hline \multicolumn{11}{|l|}{ Demographic characteristics } \\
\hline Male & $0.14 * *$ & $(0.06)$ & $-0.28 * * *$ & $(0.05)$ & $0.20 * *$ & $(0.07)$ & $-0.36^{* * *}$ & $(0.08)$ & 0.04 & $(0.05)$ \\
\hline \multicolumn{11}{|l|}{ Age (18-34) } \\
\hline $35-54$ & $0.12 *$ & $(0.07)$ & $-0.26^{* *}$ & $(0.10)$ & 0.07 & $(0.06)$ & 0.11 & $(0.09)$ & -0.02 & $(0.06)$ \\
\hline $55+$ & $0.29 * * *$ & $(0.08)$ & $-0.47 * * *$ & $(0.13)$ & -0.01 & $(0.08)$ & 0.10 & $(0.08)$ & $0.20 * *$ & $(0.09)$ \\
\hline City & $-0.25^{* * *}$ & $(0.05)$ & $0.21 * * *$ & $(0.06)$ & $-0.24 * * *$ & $(0.06)$ & $0.25^{* * *}$ & $(0.05)$ & $0.12 * *$ & $(0.05)$ \\
\hline \multicolumn{11}{|l|}{$\begin{array}{l}\text { Marital status (married or } \\
\text { partnership) }\end{array}$} \\
\hline Divorced or separated & 0.05 & $(0.08)$ & $0.19 * *$ & $(0.07)$ & -0.12 & $(0.08)$ & 0.10 & $(0.08)$ & -0.04 & $(0.06)$ \\
\hline Widowed or partner died & $-0.17 * *$ & $(0.09)$ & 0.02 & $(0.10)$ & $-0.17 * *$ & $(0.08)$ & $-0.20 * *$ & $(0.09)$ & $0.24 * * *$ & $(0.06)$ \\
\hline Single & $-0.11 *$ & $(0.06)$ & $0.21 * *$ & $(0.07)$ & $-0.11^{* *}$ & $(0.05)$ & $0.12 * *$ & $(0.04)$ & 0.02 & $(0.05)$ \\
\hline Household size & $0.04 * *$ & $(0.02)$ & 0.00 & $(0.03)$ & $0.07 * * *$ & $(0.02)$ & $-0.07 * *$ & $(0.02)$ & $-0.04^{*}$ & $(0.02)$ \\
\hline Children living at home & $-0.11 * *$ & $(0.05)$ & 0.06 & $(0.07)$ & $-0.14 * *$ & $(0.06)$ & $0.13 * *$ & $(0.06)$ & 0.07 & $(0.05)$ \\
\hline Attendance religious services & 0.03 & $(0.02)$ & $-0.08 * * *$ & $(0.02)$ & $0.23 * * *$ & $(0.02)$ & $-0.13 * * *$ & $(0.02)$ & $-0.15 * * *$ & $(0.02)$ \\
\hline Satisfaction with life & -0.01 & $(0.01)$ & -0.02 & $(0.01)$ & 0.02 & $(0.02)$ & -0.02 & $(0.01)$ & -0.00 & $(0.01)$ \\
\hline
\end{tabular}


Table 10 continued

\begin{tabular}{|c|c|c|c|c|c|c|c|c|c|c|}
\hline & \multicolumn{2}{|c|}{$\begin{array}{l}\text { Institutional } \\
\text { political } \\
\text { participation }\end{array}$} & \multicolumn{2}{|c|}{$\begin{array}{l}\text { Non-institutional } \\
\text { political } \\
\text { participation }\end{array}$} & \multicolumn{2}{|c|}{ Civic participation } & \multicolumn{2}{|c|}{$\begin{array}{l}\text { Political } \\
\text { consumerism }\end{array}$} & \multicolumn{2}{|c|}{ Non-participants } \\
\hline & $b$ & se & $b$ & $\mathrm{se}$ & $b$ & $\mathrm{se}$ & $b$ & $\mathrm{se}$ & $b$ & se \\
\hline \multicolumn{11}{|l|}{ Resources } \\
\hline \multicolumn{11}{|l|}{ Education (medium) } \\
\hline Low & 0.08 & $(0.08)$ & $-0.16^{* *}$ & $(0.07)$ & $-0.18 * *$ & $(0.07)$ & $-0.31 * * *$ & $(0.06)$ & $0.27 * * *$ & $(0.06)$ \\
\hline High & $0.10 *$ & $(0.06)$ & 0.08 & $(0.07)$ & $0.15 * *$ & $(0.06)$ & 0.09 & $(0.06)$ & $-0.38 * * *$ & $(0.05)$ \\
\hline \multicolumn{11}{|l|}{ Source of income (profit/salary) } \\
\hline Pension & 0.03 & $(0.06)$ & $-0.18 * *$ & $(0.07)$ & 0.01 & $(0.05)$ & $-0.14 * *$ & $(0.07)$ & $0.12 * *$ & $(0.04)$ \\
\hline Unemployment benefit & $0.46 * * *$ & $(0.13)$ & -0.09 & $(0.10)$ & -0.13 & $(0.13)$ & 0.01 & $(0.14)$ & 0.06 & $(0.15)$ \\
\hline Other benefit & 0.18 & $(0.20)$ & 0.11 & $(0.17)$ & -0.02 & $(0.17)$ & -0.21 & $(0.13)$ & -0.10 & $(0.13)$ \\
\hline Other & 0.10 & $(0.13)$ & -0.00 & $(0.15)$ & 0.05 & $(0.10)$ & 0.07 & $(0.16)$ & 0.02 & $(0.12)$ \\
\hline Household income & $-0.04 * *$ & $(0.02)$ & -0.00 & $(0.01)$ & 0.02 & $(0.01)$ & 0.02 & $(0.02)$ & $-0.03 * *$ & $(0.01)$ \\
\hline \multicolumn{11}{|l|}{ Political interest and efficacy } \\
\hline Ratio political news/all news & 0.07 & $(0.07)$ & $-0.14^{*}$ & $(0.07)$ & $0.29 * * *$ & $(0.08)$ & $0.40 * * *$ & $(0.09)$ & $-0.48 * * *$ & $(0.08)$ \\
\hline Political interest & $0.33 * * *$ & $(0.03)$ & $0.15 * * *$ & $(0.02)$ & 0.03 & $(0.03)$ & $0.24 * * *$ & $(0.05)$ & $-0.45 * * *$ & $(0.03)$ \\
\hline Political efficacy & $0.07 * * *$ & $(0.01)$ & 0.00 & $(0.01)$ & -0.02 & $(0.01)$ & $0.07 * * *$ & $(0.01)$ & $-0.07 * * *$ & $(0.02)$ \\
\hline \multicolumn{11}{|l|}{ Societal outlook } \\
\hline Societal pessimism & -0.05 & $(0.04)$ & $0.08 * *$ & $(0.04)$ & $-0.11 * * *$ & $(0.03)$ & $0.08 * *$ & $(0.04)$ & 0.01 & $(0.03)$ \\
\hline Political trust & $0.10 * *$ & $(0.03)$ & $-0.05^{*}$ & $(0.03)$ & 0.02 & $(0.02)$ & $-0.23 * * *$ & $(0.03)$ & $0.06 * *$ & $(0.03)$ \\
\hline Social trust & $-0.12 * * *$ & $(0.02)$ & $0.12 * *$ & $(0.04)$ & $0.12 * * *$ & $(0.03)$ & 0.03 & $(0.03)$ & $-0.12 * * *$ & $(0.02)$ \\
\hline More than 1 type of participation & $3.14 * * *$ & $(0.09)$ & $2.98 * * *$ & $(0.08)$ & $2.46 * * *$ & $(0.06)$ & $2.65 * * *$ & $(0.07)$ & & \\
\hline
\end{tabular}

Coefficients are log odds, with $* p<0.05 ; * * p<0.01 ; * * * p<0.001$ (one-sided tests)

\section{References}

Adler, R. P., \& Goggin, J. (2005). What do we mean by "civic engagement"? Journal of Transformative Education, 3(3), 236-253.

Allum, N., Patulny, R., Read, S., \& Sturgis, P. (2010). Re-evaluating the links between social trust, institutional trust and civic association. In J. Stillwell, P. Norman, \& C. Thomas (Eds.), Spatial and social disparities. Understanding population trends and processes (Vol. 2, pp. 199-215). Dordrecht: Springer.

Almond, G. A., \& Verba, S. (1963). The civic culture: Political attitudes and democracy in five nations. Princeton: Princeton University Press.

Amnå, E., \& Ekman, J. (2014). Standby citizens: Diverse faces of political passivity. European Political Science Review, 6(2), 261-281.

Armingeon, K. (2007). Political participation and associational involvement. In J. W. Van Deth, J. R. Montero, \& A. Westholm (Eds.), Citizenship and involvement in European democracies: A comparative analysis (pp. 358-383). New York: Routledge.

Bäck, M., \& Christensen, H. S. (2016). When trust matters-a multilevel analysis of the effect of generalized trust on political participation in 25 European democracies. Journal of Civil Society, 12(2), 178-197.

Badescu, G., \& Neller, K. (2007). Explaining associational involvement. In J. W. Van Deth, J. R. Montero, \& A. Westholm (Eds.), Citizenship and involvement in European democracies: A comparative analysis (pp. 158-187). New York: Routledge.
Barnes, S. H., \& Kaase, M. (1979). Political action. Mass participation in five western democracies. Beverly Hills: Sage Publications.

Bekkers, R., \& Wiepking, P. (2011). A literature review of empirical studies of philanthropy: Eight mechanisms that drive charitable giving. Nonprofit and Voluntary Sector Quarterly, 40(5), 924-973.

Bennett, O. (2001). Cultural Pessimism. Narratives of Decline in the Postmodern World. Edinburgh: Edinburgh University Press.

Benson, M., \& Rochon, T. R. (2004). Interpersonal trust and the magnitude of protest. A micro and macro level approach. Comparative Political Studies, 37(4), 435-457.

Berger, B. (2009). Political theory, political science and the end of civic engagement. Perspectives on Politics, 7(2), 335-350.

Brady, H. E., Verba, S., \& Schlozman, K. L. (1995). Beyond SES: A resource model of political participation. American Political Science Review, 89(2), 271-294.

Brehm, J., \& Rahn, W. (1997). Individual-level evidence for the causes and consequences of social capital. American Journal of Political Science, 41(3), 999-1023.

Catterberg, G., \& Moreno, A. (2006). The individual bases of political trust: Trends in new and established democracies. International Journal of Public Opinion Research, 18(1), 31-48.

Clary, E. G., \& Snyder, M. (1999). The motivations to volunteer theoretical and practical considerations. Current Directions in Psychological Science, 8(5), 156-159.

Clary, E. G., Snyder, M., Ridge, R. D., Copeland, J., Stukas, A. A., Haugen, J., et al. (1998). Understanding and assessing the motivations of volunteers: A functional approach. Journal of Personality and Social Psychology, 74(6), 1516-1530. 
Cohen, A., Vigoda, E., \& Samorly, A. (2001). Analysis of the mediating effect of personal-psychological variables on the relationship between socioeconomic status and political participation: A structural equations framework. Political Psychology, 22(4), 727-757.

Dalton, R. D. (2004). Democratic challenges, democratic choices. The Erosion of political support in advanced industrial democracies. Oxford: Oxford University Press.

Dalton, R. J. (2008). Citizenship norms and the expansion of political participation. Political Studies, 56(1), 76-98.

Dekker, P., Koopmans, R., \& Van den Broek, A. (1997). Voluntary associations, social movements and individual political behaviour in Western Europe. In J. W. Van Deth (Ed.), Private groups and public life: Social participation and political involvement in representative democracies (pp. 224-243). London: Routledge.

Easton, D. (1975). A re-assessment of the concept of political support. British Journal of Political Science, 5(04), 435-457.

Ekman, J., \& Amnå, E. (2012). Political participation and civic engagement: Towards a new typology. Human Affairs, 22(3), 283-300.

Eliasoph, N. (1998). Avoiding politics: How Americans produce apathy in everyday life. New York: Cambridge University Press.

European Commission. (2013). Public opinion in the European Union. Standard Eurobarometer 77. Retrieved from http://ec. europa.eu/commfrontoffice/publicopinion/archives/eb/eb77/ eb77_en.htm.. Accessed 22 May 2018.

Gallup. (2014). Gallup poll social series: Governance. Retrieved from http://www.gallup.com/file/poll/175799/Satisfaction 140912.pdf. Accessed 22 May 2018.

Gamson, W. A. (1968). Power and discontent. Homewood, IL: Dorsey Press.

Granik, S. (2005). A reconceptualisation of the antecedents of party activism: A multidisciplinary approach. Political Studies, 53(3), $598-620$.

Hardin, R. (2002). Trust and trustworthiness. New York: Russell Sage Foundation.

Hooghe, M., \& Marien, S. (2012). How to reach members of Parliament? Citizens and members of Parliament on the effectiveness of political participation repertoires. Parliamentary Affairs, 67(1), 1-25.

Hooghe, M., \& Marien, S. (2013). A comparative analysis of the relation between political trust and forms of political participation in Europe. European Societies, 15(1), 131-152.

Johann, D. (2012). Specific political knowledge and citizens' participation: Evidence from Germany. Acta Politica, 47(1), 42-66.

Kaase, M. (1999). Interpersonal trust, political trust and noninstitutionalised political participation in Western Europe. West European Politics, 22(3), 1-21.

Keele, L. (2007). Social capital and the dynamics of trust in government. American Journal of Political Science, 51(2), 241-254.

Keeter, S., Zukin, C., Andolina, M., \& Jenkins, K. (2002). The civic and political health of the nation: A generational portrait. Washington, DC: Center for Information and Research on Civic Learning and Engagement (CIRCLE).

Keyes, C. L. M. (1998). Social well-being. Social Psychology Quarterly, 61(2), 121-140.

Keyes, C. L., \& Shapiro, A. D. (2004). Social well-being in the United States: A descriptive epidemiology. In O. G. Brim, C. D. Ryff, \& R. C. Kessler (Eds.), How healthy are we? A national study of well-being at midlife (pp. 350-372). Chicago: The University of Chicago Press.
Kim, J. (2005). “Bowling together” isn't a cure-all: The relationship between social capital and political trust in South Korea. International Political Science Review, 26(2), 193-213.

Marien, S., Hooghe, M., \& Quintelier, E. (2010). Inequalities in noninstitutionalised forms of political participation: A multi-level analysis of 25 countries. Political Studies, 58(1), 187-213.

Mishler, W., \& Rose, R. (2005). What are the political consequences of trust? A test of cultural and institutional theories in Russia. Comparative Political Studies, 38(9), 1050-1078.

Newman, B. J., \& Bartels, B. L. (2011). Politics at the checkout line: Explaining political consumerism in the United States. Political Research Quarterly, 64(4), 803-817.

Norris, P. (2011). Democratic deficits: Critical citizens revisited. Cambridge: Cambridge University Press.

Oser, J. (2016). Assessing how participators combine acts in their "political tool kits": A person-centered measurement approach for analyzing citizen participation. Social Indicators Research, 133(1), 1-24.

Oser, J., Hooghe, M., \& Marien, S. (2013). Is online participation distinct from offline participation? A latent class analysis of participation types and their stratification. Political Research Quarterly, 66(1), 91-101.

Pattie, C., Seyd, P., \& Whiteley, P. (2003). Citizenship and civic engagement: Attitudes and behaviour in Britain. Political Studies, 51(3), 443-468.

Pattie, C., Seyd, P., \& Whiteley, P. (2004). Citizenship in Britain: Values, participation and democracy. Cambridge: Cambridge University Press.

Putnam, R. D. (1993). Making democracy work: Civic traditions in modern Italy. Princeton: Princeton University Press.

Putnam, R. D. (2000). Bowling alone. New York: Simon \& Schuster.

Quintelier, E., \& Hooghe, M. (2012). The stability of individualized collective action. Results from a panel study among Belgian late adolescents. In J. W. Van Deth \& W. A. Maloney (Eds.), New participatory dimensions in civil society: Professionalization and individualized collective action (pp. 197-211). London: Routledge.

Sabucedo, J., \& Arce, C. (1991). Types of political participation: A multidimensional analysis. European Journal of Political Research, 20(1), 93-102.

Scott, W. J., \& Acock, A. C. (1979). Socioeconomic status, unemployment experience, and political participation: A disentangling of main and interaction effects. Political Behavior, 1(4), $361-381$.

Steenvoorden, E. H. (2015). A general discontent disentangled: A conceptual and empirical framework for societal unease. Social Indicators Research, 124(1), 85-110.

Steenvoorden, E. H., \& Harteveld, E. (2017). The appeal of nostalgia: The influence of societal pessimism on support for populist radical right parties. West European Politics, 41(1), 1-25.

Steenvoorden, E. H., \& Van der Meer, T. W. G. (2017). Continent of pessimism or continent of realism? A multilevel study into the impact of macro-economic outcomes and political institutions on societal pessimism, European Union 2006-2012. International Journal of Comparative Sociology, 58(3), 192-214.

Stolle, D., \& Hooghe, M. (2011). Shifting inequalities: Patterns of exclusion and inclusion in emerging forms of political participation. European Societies, 13(1), 119-142.

Stolle, D., Hooghe, M., \& Micheletti, M. (2005). Politics in the supermarket: Political consumerism as a form of political participation. International Political Science Review, 26(3), 245-269.

Suh, H., Yee, J., \& Chang, D. (2013). Type of trust and political participation in five countries. Development and Society, 42(1), $1-28$. 
Teorell, J., Torcal, M., \& Montero, J. R. (2007). Political participation: Mapping the terrain. In J. W. Van Deth, J. R. Montero, \& A. Westholm (Eds.), Citizenship and involvement in European democracies: A comparative analysis (pp. 334-357). New York: Routledge.

Uslaner, E. M. (2002). The moral foundations of trust. Cambridge: Cambridge University Press.

Uslaner, E. M., \& Brown, M. (2005). Inequality, trust, and civic engagement. American Politics Research, 33(6), 868-894.

Van der Meer, T. (2009). States of freely associating citizens: Comparative studies into the impact of state institutions on social, civic and political participation. PhD thesis, Radboud Universiteit Nijmegen, Nijmegen.

Van der Meer, T., Te Grotenhuis, M., \& Scheepers, P. L. (2009). Three types of voluntary associations in comparative perspective: The importance of studying associational involvement through a typology of associations in 21 European countries. Journal of Civil Society, 5(3), 227-241.

Van Deth, J. W. (2001). The proof of the pudding: Social capital, democracy and citizenship. Paper presented at EURESCO conference "social capital: Interdisciplinary perspectives, Exeter, 15-20 September (Presented at the ESF/EURESCO conference "Social capital-Interdisciplinary perspectives" Exeter, UK, September 2001)
Van Deth, J. W. (2012). New modes of participation and norms of citizenship. In J. W. Van Deth \& W. A. Maloney (Eds.), New participatory dimensions in civil society: Professionalization and individualized collective action (pp. 115-138). London: Routledge.

Van Deth, J. W. (2014). A conceptual map of political participation. Acta Politica, 49(3), 349-367.

Vecchione, M., \& Caprara, G. V. (2009). Personality determinants of political participation: The contribution of traits and self-efficacy beliefs. Personality and Individual Differences, 46(4), 487-492.

Verba, S., \& Nie, N. H. (1972). Participation in America. Political democracy and social equality. Chicago: The University of Chicago Press.

Vráblíková, K. (2013). How context matters? Mobilization, political opportunity structures, and nonelectoral political participation in old and new democracies. Comparative Political Studies, 47(2), 203-229.

Zmerli, S., \& Newton, K. (2017). Objects of political and social trust: Scales and hierarchies. In S. Zmerli \& T. Van der Meer (Eds.), Handbook on Political Trust (pp. 104-124). Cheltenham: Edward Elgar Publishing. 